\title{
Impact of zinc and lead on soil respiration and microbial content under in vitro conditions
}

\author{
Abdousalam Ahmed. Algaidi \\ Faculty of Agriculture, Sebha University, Libya \\ E-mail: algaidiaa@yahoo.com \\ Address: Sebha. Libya. P.O.Box 19988
}

\begin{abstract}
The habitation and activities of soil aerobic bacteria living in the sandy clay soil were affected by the toxicity of Zinc and Lead ions at different levels. Their inhibitory effect was manifested directly in the decrease of the total aerobic bacteria counts in the soil and physiological activity of the soil aerobic bacteria. Aerobic bacteria population generally decreased similarly to the $\mathrm{CO}_{2}$-production in response to the toxic effects of the investigated metal ions. The soil samples were metabolically activated by $\mathrm{C}, \mathrm{N}$ and $\mathrm{P}$ in the form of sodium nitrate, potassium phosphate and glucose, respectively as substrate-induced respiration. The inhibitions of biological activities in the soil samples were appeared even after three weeks, but highly significant effects were obtained after six-week incubation period. Lead had smallest effects on decreasing $\mathrm{CO}_{2}$-production at different incubation intervals. The strongest inhibition of the gas production was detected by the influence of Zinc ions.
\end{abstract}

Keywords: heavy metals - soil aerobic bacteria-toxicity

\section{INTRODUCTION}

The fertility of natural soil ecosystem depends significantly on the rate of turnover of soil organic matter, mediated by the soil microbial biomass. In agricultural ecosystems, soil fertility can be increased by applications of inorganic or organic fertilizer. The fertility of natural ecosystem, however, depends almost entirely on natural microbial processes, including $\mathrm{N}_{2}$ fixation, the mineralization of organic matter of $\mathrm{N}, \mathrm{C}, \mathrm{P}$ and $\mathrm{S}$ and organic matter transformations, all mediated by the soil microbial biomass. Soil microbial biomass is considered to be the agent of breakdown of organic matter in the soil, although the importance of its size in relation to nutrient cycling and decomposition processes is poorly understood. It is well known that microbial biomass increases when organic materials are applied to soil. However, Brookes \& McGrath (2007) showed that microbial biomass in soil from the classical Woburn Marketgarden Experiment which had been supplied with an aerobically digested lagoon-dried sewage sludge was half that in soil that had received farmyard manure. Sludge application increased soil metal concentrations up to current limits with the exception of $\mathrm{Cd}$ which was three to five times the maximum limit (Brookes et al 1999, McGrath et al 1988). However, in other studies with the same soils (Brookes et al 2000) there were no effects of metal concentration on respiration rate. Therefore, the respiration rate per unit weight of biomass was considerably greater in the metalcontaminated soil. This response may not necessarily be detrimental, but could be explained because metal-sensitive species have been replaced by other more tolerant groups that respire at a higher rate. Alternatively, the effect could be interpreted as a metal-induced stress response. Soluble metal salts have been applied to soils often as a basis for 
assessing effects of heavy meals in sewage sludge on soil $\mathrm{N}$ transformation were summarized by Doelman (2006). It was concluded that, in general, increasing soil metal levels may reduced the composition and diversity of the total soil microbial population, causing a shift towards resistant strains that become dominant in such soils. Increasing abundance of resistant strains under elevated metal conditions enables the continuation of essential processes that maintain soil fertility (Barkay et al 1985).

The supply of mineralized $\mathrm{C}, \mathrm{N}$, and $\mathrm{P}$ from soil organic matter, the decomposition of plant and animal residues and the maintenance of soil structure are all-dependent upon the correct functioning of the soil microbial ecosystem Doelman \& Haanstra (1999) carried out short-term and long-term effects of $\mathrm{Cd}, \mathrm{Cr}, \mathrm{Cu}, \mathrm{Ni}, \mathrm{Pb}$ and $\mathrm{Zn}$ on soil microbial respiration in relation to a biotic soil factors. It was found that in short-term effects of $\mathrm{Pb}$ in sand were distinct, while in sandy loam, the inhibitory effect was not significant, but after 43 weeks, it had increased significantly. In silty loam and clay, there were no significant inhibitory effects. In general, the heavy metals were found to be more toxic during the first eight weeks than after an extended period. It was concluded that toxicity of heavy metals in soil decreases with time, as well as the a biotic factor was found to be the dominant factor in decreasing the toxicity of $\mathrm{Pb}$ and to a lesser extent of $\mathrm{Zn}$.

The objectives of present study were: 1) to measure soil respiration $\left(\mathrm{CO}_{2}\right.$ evolution) as bio indicator parameter of soil contamination. 2) to study the effect of heavy metal on microbial survival and activity in heavy metal amended soil under laboratory incubations. 3 ) to detect the bioavailability of investigated metal in assayed soil.

\section{MATERIALS AND METHODS}

Soil and treatments: The sandy clay soil samples were collected from cultivated area. The physical and chemical properties of the studied soil are: $\mathrm{pH}_{(\mathrm{KCl})}$ 6.97 , humus content $1.21 \%, \mathrm{C}: \mathrm{N}$ ratio 12.4, and the following properties are in $\mathrm{mg} \mathrm{kg}{ }^{-1}: \mathrm{NH}_{4}{ }^{+}-\mathrm{N}$ (3.2), $\mathrm{NO}_{3}{ }^{-}-\mathrm{N}$ (4.5), $\mathrm{SO}_{4}^{-2}$ (4.6), $\mathrm{K}_{2} \mathrm{O}$ (123), $\mathrm{P}_{2} \mathrm{O}_{3}(209), \mathrm{Cu}$ (1.86), Mg (206), Mn (195), Cd (0.065), Co (1.57), $\mathrm{Pb}$ (8.48), and $\mathrm{Zn} \mathrm{(7.22).} \mathrm{The}$ experiment was carried out by air-dried soil. The determination of bioavailability and the effect of heavy metals $(\mathrm{Pb}$ and $\mathrm{Zn})$ on $\mathrm{CO}_{2}$-production and total count of the aerobic bacterial population in soil samples were carried out in control and treated soil samples. Materials in the form of sodium nitrate $\left(170 \mathrm{mg} \mathrm{kg}^{-1}\right)$, potassium phosphate $\left(50 \mathrm{mg} \mathrm{kg}^{-1}\right)$, and glucose $\left(3 \mathrm{mg} \mathrm{kg}^{-1}\right)$ were as sources of $\mathrm{N}$, $\mathrm{P}$, and $\mathrm{C}$, respectively, and activated the soil samples. All activated, nonactivated, cultivated soil samples were treated with three concentrations of $\mathrm{Zn}$ in form of $\mathrm{ZnCl}_{2}\left(1.5,3\right.$, and $\left.6 \mathrm{mg} \mathrm{kg}{ }^{-1}\right)$, and $\mathrm{Pb}$ in the form of $\mathrm{PbCl}_{2}(40,80$ and $160 \mathrm{mg} \mathrm{kg}^{-1}$ ). The heavy metal amended soil samples were incubated for six weeks. The counting the total aerobic bacterial population and the amount of $\mathrm{CO}_{2}$-production in each soil sample were investigated after first, third and six weeks of incubation at $28{ }^{\circ} \mathrm{C}$.

Determination of $\mathrm{CO}_{2}$-production: For measurement of $\mathrm{CO}_{2}$-production, a 0.5 $\mathrm{kg}$ of the heavy metal treated soil was filled in 1.5 1-glass vessels and in the middle of the soil a fixed plastic tube, containing $50 \mathrm{ml}$ of $10 \mathrm{M} \mathrm{NaOH}$ solution for trapping the evolution of $\mathrm{CO}_{2}$ and vessel was closed tightly. The $\mathrm{NaOH}$ was titrated with $\mathrm{HCl}(1 \mathrm{M})$ to calculate the volume of $\mathrm{CO}_{2}$ released as soil respiration, which represented the 1) respiration due to litter decomposition, 2) root respiration, 3) rhizo-microbial respiration (i.e. microbial respiration utilizing $\mathrm{C}$ directly derived from living roots), and 4) microbial respiration 
utilizing native soil organic matter. Applied method of Wardle \& Parkinson (1991) was used for simultaneous determination of $\mathrm{NaOH}$ and $\mathrm{Na}_{2} \mathrm{CO}_{3}$ content in our experimental soil samples.

Determination of total available fraction: MI $-08-1735-1990$ is the Hungarian technical directive method which was used to detect $\mathrm{Zn}$ and $\mathrm{Pb}$ content in the soil samples. Five gram of air-dry and find grounded soil sample was weighed and shaked with $25 \mathrm{~cm}^{3}$ of $1.5 \mathrm{M}$ nitric acid at $20^{\circ} \mathrm{C}$ for two hours. The element analysis of the filtrate was performed by jobin-Yvon 24 type ICP atomic emission spectrometer.

Determination of total number of aerobic bacteria: Under sterile conditions, a $10 \mathrm{~g}$ of fresh soil sample was suspended with $90-\mathrm{cm}^{3}$ water. The soil suspension was diluted gradually to $10^{-3}$ and $10^{-6}$ and from the diluted suspensions $1 \mathrm{~cm}^{3}$ was pipetted in (Petri dish, and mixed thoroughly with Nutrient agar). The plates were incubated on 27 ${ }^{\circ} \mathrm{C}$ for 48 hours. After that, the developed bacterial colonies were counted.

All experiments were carried out in three replicates, and the results were represented by the means of the replicates.

\section{RESULTS AND DISCUSSION}

The effect of CNP and heavy metals on $\mathrm{CO}_{2}$-production and bacterial population of sandy clay soil was studied in laboratory conditions. This study is concerned with the effect of CNP and heavy metals $\mathrm{Zn}$ and $\mathrm{Pb}$ on $\mathrm{CO}_{2}$-production as well as bacteria populations of sandy clay soil during one, three and six weeks incubation. After a week incubation, the recovery of $\mathrm{Zn}$ and $\mathrm{Pb}$ concentrations added to CNP treated sandy clay soils was determined in the nitric acid soluble faction. Data presented in Fig.1. Show that the addition of inorganic forms of $\mathrm{Zn}$ and $\mathrm{Pb}$ significantly increases the mobile $\left(\mathrm{HNO}_{3}\right.$ soluble) fraction of these metals but after week incubation their concentration does not reach the $100 \%$ recovery. It can be observed that the methods used for biomass, $\mathrm{CO}_{2}$-evolution and total bacteria number, are both suitable to be indicators for biomass measurements through which we can have an idea about the soil fertility. It is known that microbial biomass plays an important role in mineral nutrition of soil.

The effect of heavy metal treatments on $\mathrm{CO}_{2}$ reduction in $\mathrm{CNP}$ fertilized soil is showed in Fig. 1. It is clear from data presented that CNP treated sandy clay soil showed higher rate of $\mathrm{CO}_{2}$-production, estimated by $0.57,0.58$ and $0.63 \mathrm{ml} / 100 \mathrm{~g}$ soil/hour, in sandy clay soil comparing with $0.31,0.29$ and $0.30 \mathrm{ml} / 100 \mathrm{~g}$ soil/hour in CNP sandy clay soil during all three different incubation periods $\left(1^{\text {st }}\right.$ week, $3^{\text {rd }}$ week and $6^{\text {th }}$ week).

Data recorded in Fig. 2. Show that CNP treated sandy clay soil samples have higher bacterial population (which are representing in term of $\log$ of bacterial colonies) than in untreated ones during the three different periods $\left(1^{\text {st }}\right.$ week, $3^{\text {rd }}$ week and $6^{\text {th }}$ week). These previous results are in accordance with the results found by De Haan et al. (1999) who reported that the supply of mineralized $\mathrm{C}, \mathrm{N}$ and $\mathrm{P}$ from soil organic matter, the decomposition of plant and animal residues and the maintenance of soil structure are all dependent upon the correct functioning of the soil microbial ecosystem. The beneficial effects of sewage sludge's due to the extra organic matter $\mathrm{N}$ or $\mathrm{P}$ supplied may be short lived. These results are also in accordance with investigation of Hossain et al. (2005). Hossain et al. (2005) have discussed the effects of fertilizer. It was reported that only the lime plus $\mathrm{P}$ and $\mathrm{N}$ plus $\mathrm{P}$ treatments significantly affected soil microbial biomass $\mathrm{C}$ content. The $\mathrm{N}$ plus $\mathrm{P}$ treatment increased biomass $\mathrm{C}$ content. Microbial specific respiratory activity was higher in the unfertilized treatments. Nannipieri et al. (1990) stated that the changes in $\mathrm{CO}_{2}$-evolution were related to glucose concentrations of mineral nutrients. Higher initial rates of $\mathrm{CO}_{2}$-evolution were noted after the addition of $\mathrm{P}$ and glucose to $\mathrm{N}$ amended soil at C: P ratios greater than 30:1. It's also shown from such data presented in Fig. 1. Those heavy metals, $\mathrm{Zn}$ and $\mathrm{Pb}$ have significant effect on $\mathrm{CO}_{2}$-production of tested sandy clay soil at different incubation periods ( $1^{\text {st }}$ week, $3^{\text {rd }}$ week, and $6^{\text {th }}$ week). 

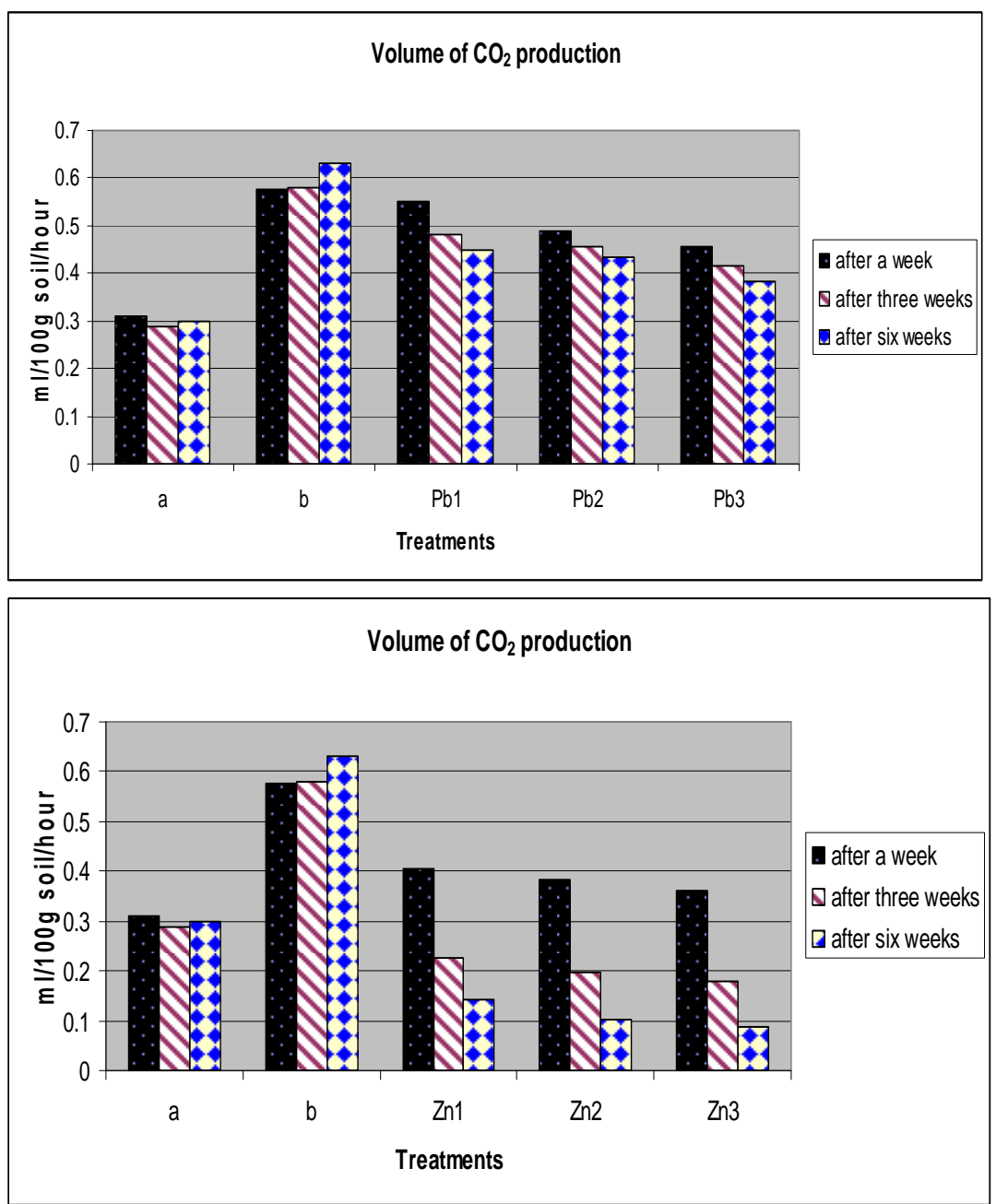

Fig. 1: Average of $\mathrm{CO}_{2}$-production volume at $25^{\circ} \mathrm{C}, 0.1 \mathrm{MPa}(\mathrm{ml} / 100 \mathrm{~g}$ soil per an hour) of sandy clay soil treated by CNP and heavy metals for different three periods (a: CNP untreated soil, b: CNP treated soil).

$\mathrm{Pb}$ at different concentrations, 40 , 80 , and $160 \mathrm{mg} / \mathrm{kg}$ have the smallest effect on decreasing $\mathrm{CO}_{2}$-production either in sandy clay soil incubated at different periods. It can be shown also from data that $\mathrm{Zn}$ has higher effects in decreasing the amount of $\mathrm{CO}_{2}-$ production at the different concentration used, 1.5, 3, and $6 \mathrm{ppm}$ for $\mathrm{Zn}$ either in sandy clay soil at the three different periods. Baath (2002) studied the effect of heavy metals in soil microbial processes and populations. $\mathrm{He}$ established that the relative toxicity of different metals decreased in the order $\mathrm{Cd}>\mathrm{Cu}>\mathrm{Zn}>\mathrm{Pb}$. His results were similar to our result in which our investigation showed that the relative toxicity of tested metals decreased in the order $\mathrm{Pb}>\mathrm{Zn}$.

A significant effect of heavy metals, lead and zinc on bacterial population has been found in CNP treated or untreated soils (Fig. 2.). It is shown that $\mathrm{Zn}$ has much more significant effect in decreasing bacterial population than $\mathrm{Pb}$ that has a little effect. It is also clear that the higher concentration of $\mathrm{Pb}$ and $\mathrm{Zn}$ cause decreases in total bacterial population. Concerning the effect of $\mathrm{Pb}$ and $\mathrm{Zn}$ on the $\mathrm{CO}_{2}$-production and its relation to the sampling time, it is obvious that there is a clear trend. In the two heavy metal treatments, $(\mathrm{Pb}$ and $\mathrm{Zn})$, the highest $\mathrm{CO}_{2}$-production was measured after the $1^{\text {st }}$ week incubation followed by the $3^{\text {rd }}$ and $6^{\text {th }}$ week 
respectively. The same effect was found for the bacterial population. This result is in accordance with the result of Leita et al. (1995) who reported that the addition of $\mathrm{Pb}$ did not have any significant inhibitory effect on the level of microbial biomass.
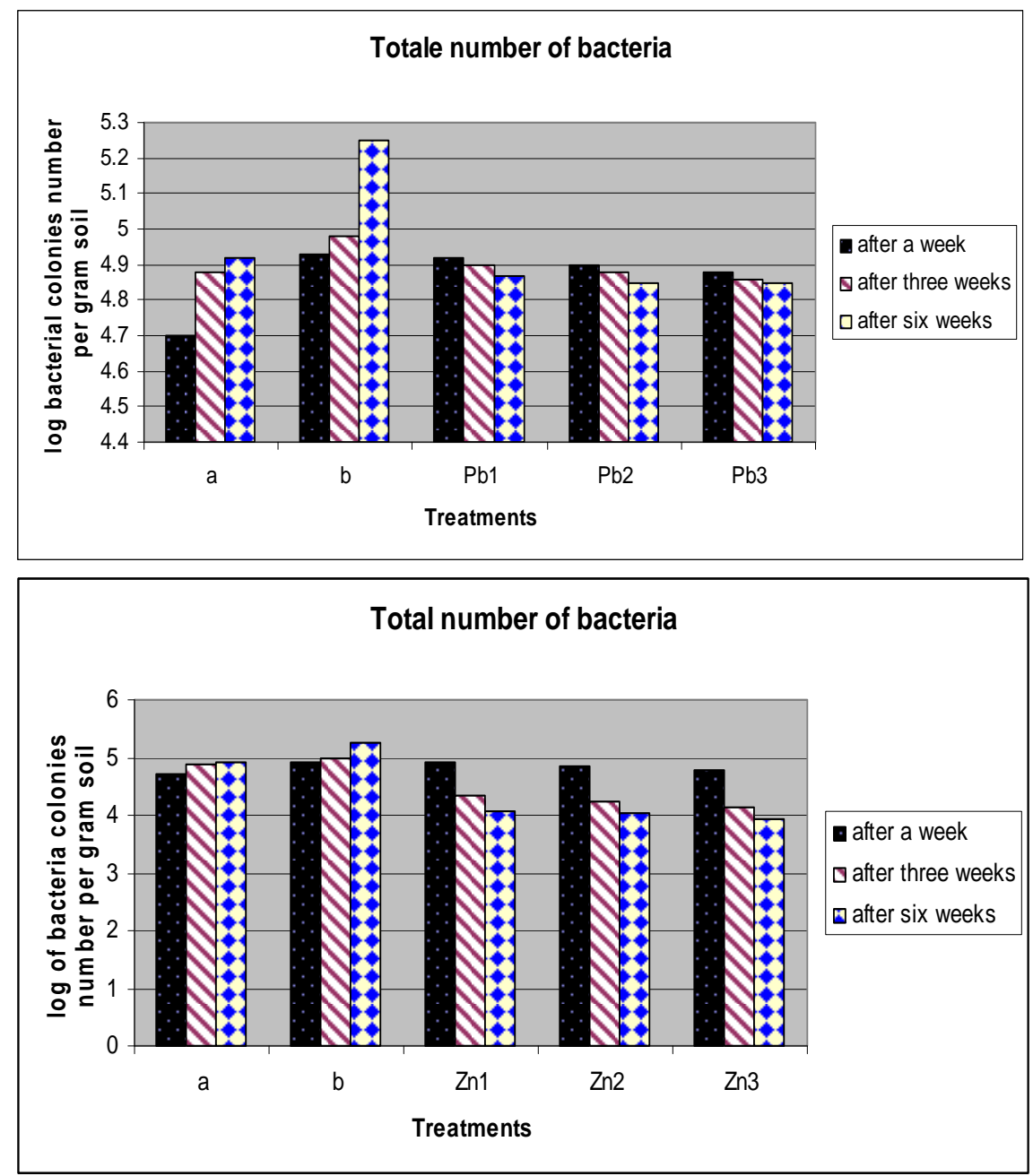

Fig. 2: Average of log of total bacterial number of sandy clay soil treated by CNP and heavy metals after different three periods (a: CNP untreated soil, b: CNP treated soil).

\section{CONCLUSION}

It can be concluded that 1 . Incubation time is an important factor for metal recovery in soil, 2. Soil respiration is a detectable method for measurement the toxicity of the metal and it can be considered that this method might be an indicator of soil metal contamination, and 3. The heavy metals have the important concern in microbial populations in the investigated soil samples.

\section{REFERENCES}

Baath, E. (2002): Effects of heavy metals in soil metals on microbial processes and population (a review). Water Air Soil Pollut., 47: 335-346.

Barkay T., Tripp S.C., Olson B.H. (1985): Effect of metal-rich sewage sludge application on the bacterial communities of grassland. Appl. Environ. Microbiol., 49: 333-337.

Brookes P.C., McGrath S.P. (2007): Effect of metal toxicity on the size of the soil microbial biomass. J. Soil Sci. 35: 341346.

Brookes P.C., McGrath S.P., Heijnen C.E. (1999): Metal residues in soils previously treated with sewage sludge and their effects on growth and nitrogen 
fixation by blue-green algae. Soil Biol. Biochem., 18: 345-355.

Brookes P.C., McGrath S.P., Klein D.A., Elliott E.T. (2000): Effects of heavy metals on microbial activity and biomass in field soils treated with sewage sludge. Environmental Contamination (Internat. Conf., London, July 2000) CEP Ltd, Edinburgh, UK, pp. 574-583.

De Haan, F.A.M., Bourg, A.C.M., Brookes, P.C., Verstraete, W., van Riemsdijk, W.H., van der Zee, S.E.A.T.M., Giraldez, J.V., and McGrath S.P. (1999): Soil quality assessment. State of the art report on soil quality. Final report to the C.E.E. Directorate-General XII, Science, Research and Development Directorate E., Environment and Non-Nuclear Energy Contract EV4A/0008/NL.

Doelman P. (2006): Resistance of soil microbial communities to heavy metals. In: FEMS Symposium, No. 33. Microbial Communities in Soil, Copenhagen, Aug. 4-8 1985. Elsevier Applied Science Publishers Ltd, London, UK., pp. 369-398.

Doelman P. - Haanstra L. (1999): Short-term and long-term effects of cadmium, chromium copper, nickel, lead and zinc on soil microbial respiration in relation to abiotic soil factors. Plant and Soil, 79: 317-327.
Hossain, A.K.M.A., Raisson, R.J., and Khanna, P.K. (2005): Effects of fertilizer application and fire regime on soil microbial biomass carbon and nitrogen, and nitrogen mineralization in an Austrialian subalpine eucalypt forest. Biol. Fertil. Soils, 19: 246-252.

Leita, L., De-Nobil, M., Muhlbachova, G., Mondini, C. and Zerbi, G. (1995): Bioavailability and effects of heavy metals on soil microbial biomass survival during laboratory incubation. Biol. Fertl. Soils. 19: 103-108.

McGrath S.P., Brookes P.C., Giller K.E. (1988): Effects of potentially toxic metals in soil derived from past applications of sewage sludge on nitrogen fixation by Trifolium repens $\mathrm{L}$. Soil Biol. Biochem., 20: 412-424.

MI-08-1735-1990 (1990): A szennyvízben megenhető káros és mérgező komponensek határértékei szántóföldi szennyvízhasznosítás esetén.

Nannipieri P., Grego S., Ceccanti B. (1990): Ecological significance of the biological activity in soil. Soil Biochem., 6: 293355.

Wardle D.A., Parkinson D. (1991): Analysis of co-occurrence in a fungal community. Mycol. Res., 95: 504-507.

\section{ARABIC SUMMARY}

\section{أثر الزتك والرصاص على تنفس التربة ومحتواها الميكروبي في ظروف مختبريه}

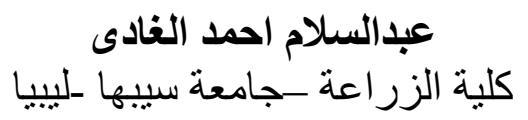

تأثر عيش ونشاطات بكتيريا التربة الحي هو ائبة التي تعيش في التربة الطينية الرملية بسمية الزنكا و أيونات

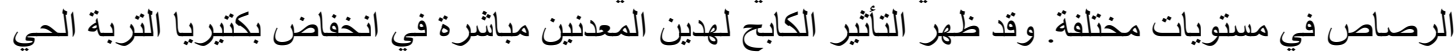

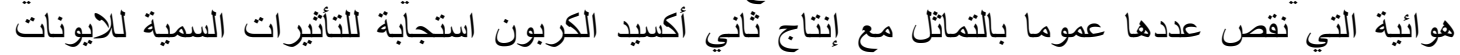

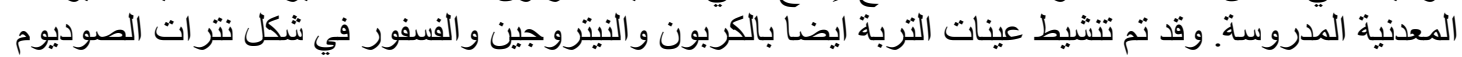

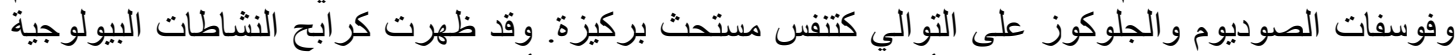

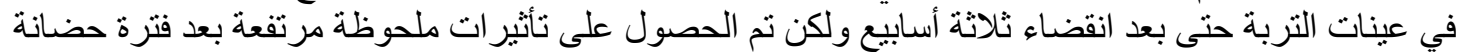

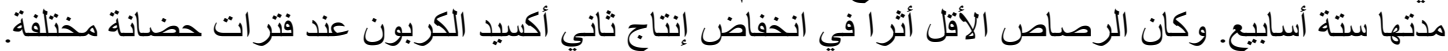

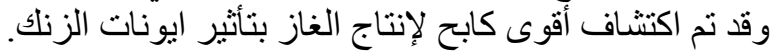

